\title{
A Nap tükröződése vektorszámítással és egy szerencsés esemény ismertetése
}

\author{
A repülőgépek tájékozódását nehezíti a repülögép személyzetét el- \\ vakító, esetleg tükröződő, fénysugár. Ismert a szándékosan lézerrel \\ okozott zavar, de a természettől adódó tükrözéssel is történt ilyen \\ esemény. Nem csak a változó irányú horizont közeli Nap, hanem a \\ tükröző felületekről visszaverődő napsugár is zavaró lehet. Tükrö- \\ ződnek az üvegezett felületek, vízfelületek, stb. A számítások és a tu- \\ dományos alapok leírása mellett egy majdnem tragikussá váló, óceán \\ felett lejátszódó repülőeseményt is ismertet a cikk.
}

DOI 10.24228/KTSZ.2019.3.3

\section{dr. Becske Loránd}

ITM - Közlekedésbiztonsági Szervezet főosztályvezető

lorand.becske@itm.gov.hu

\section{dr. Sobor Ákos}

nyugalmazott hatósági felügyelő

Polgári Légiközlekedési Hatóság

sobor.akos@gmail.com

\section{A NAPSUGÁR VAGY TÜKRÖZÖ- DÉSÉNEK ZAVARÓ HATÁSA A REPÜLÖGÉPEK TÁJÉKOZÓDÁ- SÁBAN}

A közlekedés biztonságát nagymértékben veszélyezteti az egy helyre koncentrálódó erős fényforrás. Gondoljunk csak arra az esetre, amikor egy szembejövő jármü az országúti világítását nem kapcsolja át tompított fényre. A szemünkbe jutó fénysugár vonalától nagyobb térszögben sem tudunk megfelelően tájékozódni, és a fényforrás elhaladtával sem adaptálódik kellő gyorsasággal látásunk a környezeti vagy az elötte fennálló fényviszonyokhoz. Különösen igaz ez a kínzóan vakító jelenség, ha a Napba nézünk. Ha szemünkben $4 \mathrm{mWs}$ napenergia jut a retinánkra, ott hővé alakul, rövid ideig elveszítjük látásunkat, esetleg látáskárosodást is okoz[1]. Ez különösen veszélyes lehet a megközelítési eljárás közben és a siklópálya szakaszon, ha a Nap a nem kitakarható térszögben tartózkodik a horizont közelében. Ugyanez érvényes abban az esetben is, ha ez még lapos szögben történő tükröződéssel párosul. A tükröződés általánosan véve $15 \%$ körüli, de ez síküveg törésmutatója esetén $45^{\circ}$ beesési szög alatti értéknél már teljes visszaverődéssel párosul [3].

\section{MILYEN ESETEKBEN LEHET A TÜKRÖZÖDÉS ZAVARÓ?}

Tavak, tengerek, lassú folyású folyók, állóvizek esetén a tükrözés síkja vízszintes. Épületeknél, napkollektor vagy napelem táblák esetén a tükrözés síkja, a vízszintestől változó szöggel térhet el. Lehetnek függőleges helyzetüek is nagy üvegfelületű épületek esetén.

A repülöterek nagy területen helyezkednek el, és csábító az a gondolat, hogy a kihasználatlan területeket kiadják napenergia termelés céljára, így például a fünyírás nem jelent külön 


\section{Légi közlekedés}

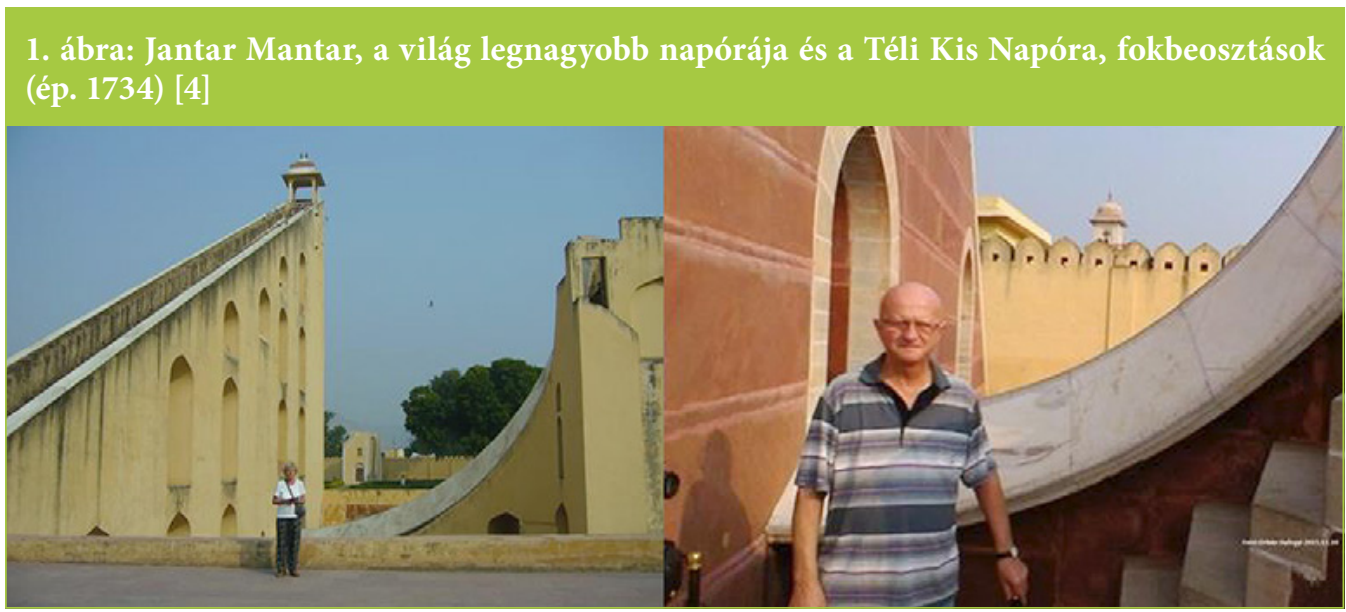

költséget, illetve a talaj gondozása a napenergiát termelö feladata. Ha kellő gonddal telepítik az óriási felületen akár a napelemeket, akár napkollektorokat, akkor nem kell korlátozó feltételeket elöírni a repülötér napszakonkénti, esetleg évszakonkénti üzemeltetése során.

A Nap pályája évszakonként és napszakonként változik. Az azimut (az a szög, amelyet valamely égi vagy földi objektumon áthaladó magassági kör képez a meridiánnal) és a napmagasság szögeiből kiválasztható a napszak szerint a Nap irányvektora. Ezt az irányvektort a visszaverő felület merölegesére térben tükrözve kapjuk meg a tükrözés irányvektorát a földrajzi helyhez kötötten, komponensei szerint. Így mód nyílik arra, hogy az év napjaira megadható legyen a tükröződés irányvektorának térbeli elhelyezkedése mind horizontálisan, mind vertikálisan. A napvektor beesési síkja É-D irányban a pontos földrajzi időt mutatja. Például egy óriási napóra az indiai Jaipurban található (1. ábra).
Ebből a felismerésből, - hogy egy kiválasztott földrajzi hosszúsági foknál mindig a napszak szerint adott időpontban adott helyre mutat ez a sík - indulunk ki a számítási eljárás kidolgozása során.

\section{A NAP TÜKRÖZÖDÉS IRÁNYVEK- TORÁNAK SZÁMÍTÁSA [3], [7]}

Az egyenlítő és az ekliptika síkja egymással 23,50-os szöget zár be. Más szóval az ekliptika normálisa, amely merőleges a síkjára és a Föld

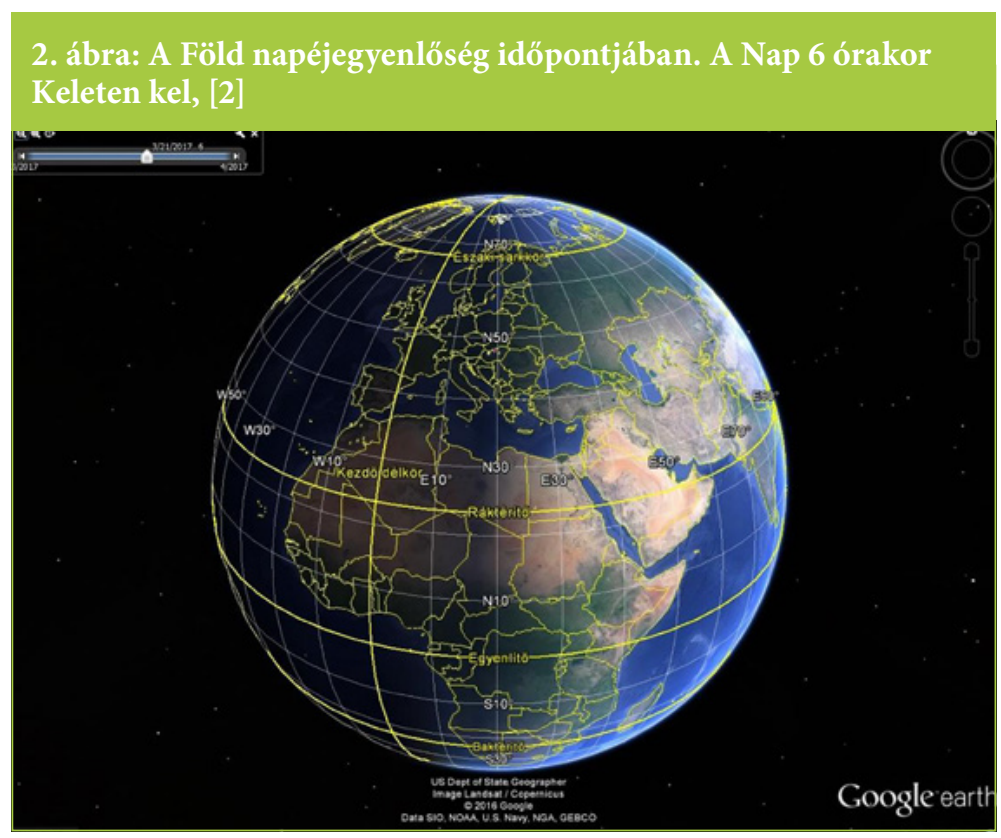


forgástengelye közötti szög szintén ekkora. Nyári napfordulókor ez a $23,5^{\circ}+90^{\circ}$ - földrajzi szélességi fok adja meg a legnagyobb delelési magasságot. A $23,5^{\circ}$ az év napjai elteltével változik. Ezt a hozzáadott szögértéket nevezzük deklinációnak. Jelölése $\delta$. Nulla értéket a tavaszi napéjegyenlőség idején ér el. Téli napfordulókor ez a minimumérték természetesen $-23,5^{\circ}$. Nem követünk el számottevő hibát, ha ennek az értéknek a változását szinusz függvénnyel közelítjük. (Kepler II. törvény. A Föld ellipszis pályán kering a fókuszpont körül, és a vezérsugara egyenlő területet súrol azonos idő alatt. Az excentricitása pedig nagyon kicsi, 0,0167) [6].

A Föld 6 órától kezdődően, 12 óra alatt fordul Kelettől Nyugatig. Ezt nagyon kis hibával 365 napon keresztül teszi meg, és ha zéruspontját az év 81. napjára tesszük, akkor a napok sorszámát n-nel jelölve naponként megállapítható a deklináció évi alakulása [3].

$$
\delta^{\circ}=23,5+\sin \left(2 \pi \frac{284+n}{365}\right)
$$

Fontos jellemzők [3], [7]:

- napmagasság: $\mathbf{m}^{\circ}$ a helyi vízszintestől mért szöge a Napnak a Föld elfordulása során (helyi szögmagasságok, van cosinus és sinus összetevője),

- azimut $\mathbf{a}^{\mathbf{o}}$ : a Nap déli iránytól való eltérése a vízszintes síkon,

- a koordináta rendszer felvétele: $\mathrm{X}$ tengely Nyugat, Y tengely Dél, $Z$ tengely a magasság,

- A tükröző tárgy normál egységvektorát úgy képezzük, hogy megadjuk a tükör hosszát, azt fel- vagy lefelé a kívánt mértékben elmozdítjuk, ebből számítható a dőlésszög, és a kívánt mértékben elforgatva az i, j, k vektor komponensek számíthatók $90^{\circ}$ forgatás után. A tényleges hosszal való osztás után egységvektort képezünk, amit más módon is meg lehet adni, közvetlenül az elképzelt komponensekkel.
A mindenkori napmagasságot a naptári dátum, a földrajzi szélesség és a helyi idő függvényében tudjuk meghatározni [3], [7]

$\sin m=\sin \delta \sin \Psi+\cos \delta \cos \Psi \cos \omega$

A hozzátartozó azimut

$\sin a=\frac{\cos \delta}{\cos m} \sin \omega$

$\Psi$ A tükröző felület földrajzi szélessége,

$\omega \mathrm{Az}$ óraszög, reggel 6 órakor $-90^{\circ}, 18$ órakor $90^{\circ}$.

A napmagasságnak mind szinuszos, mind koszinuszos összetevője számítható, és az azimuttal számítható a napmagasság $\mathrm{N}$ vektorának mindhárom összetevője $\left(\mathrm{N}_{\mathrm{i}}, \mathrm{N}_{\mathrm{i}}, \mathrm{N}_{\mathrm{k}}\right)$ [5].

A tükör normálisának vektorát úgy adhatjuk meg, hogy déli iránytól elforgatva az egyik végénél megfogott ismert hosszú tükör másik végét süllyesztjük, és kiszámítjuk a lejtésre merőleges egységvektort. Jelöljük $T_{i}, T_{j}, T_{k}$-val az összetevőket

A napvektort $\mathrm{N}$ és a $\mathrm{T}$ vektorok skalár szorzatából megállapítható a közbezárt szög [5].

$$
\begin{gathered}
N \cdot T=N i \cdot T i+N j \cdot T j+N k \cdot T k \\
\cos \varphi=\frac{N \cdot T}{/ N / \cdot / T /}
\end{gathered}
$$

Egységvektorokról van szó!

Ez lesz az $\underline{N}$ napvektor $\underline{T}$ a tükör normálvektor irányú vetülete. A vetület vektorral a napvektort összekötő $\underline{\Delta}$ meröleges a $\underline{\mathrm{T}}$ tükör vektorra. $\mathrm{Az} \underline{\mathrm{N}}$ vetülete és a $\underline{\mathrm{T}}$ vektor hányadosával megszorozva zsugorítjuk a T’ vektor komponenseit, majd $\underline{T}$-höz hozzáadva $\underline{\Delta}$ különbség vektort megkapjuk a tükörkép $\underline{\mathrm{V}}$ vektort, vagyis a visszaverődés irányát.

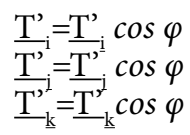




\section{Légi közlekedés}
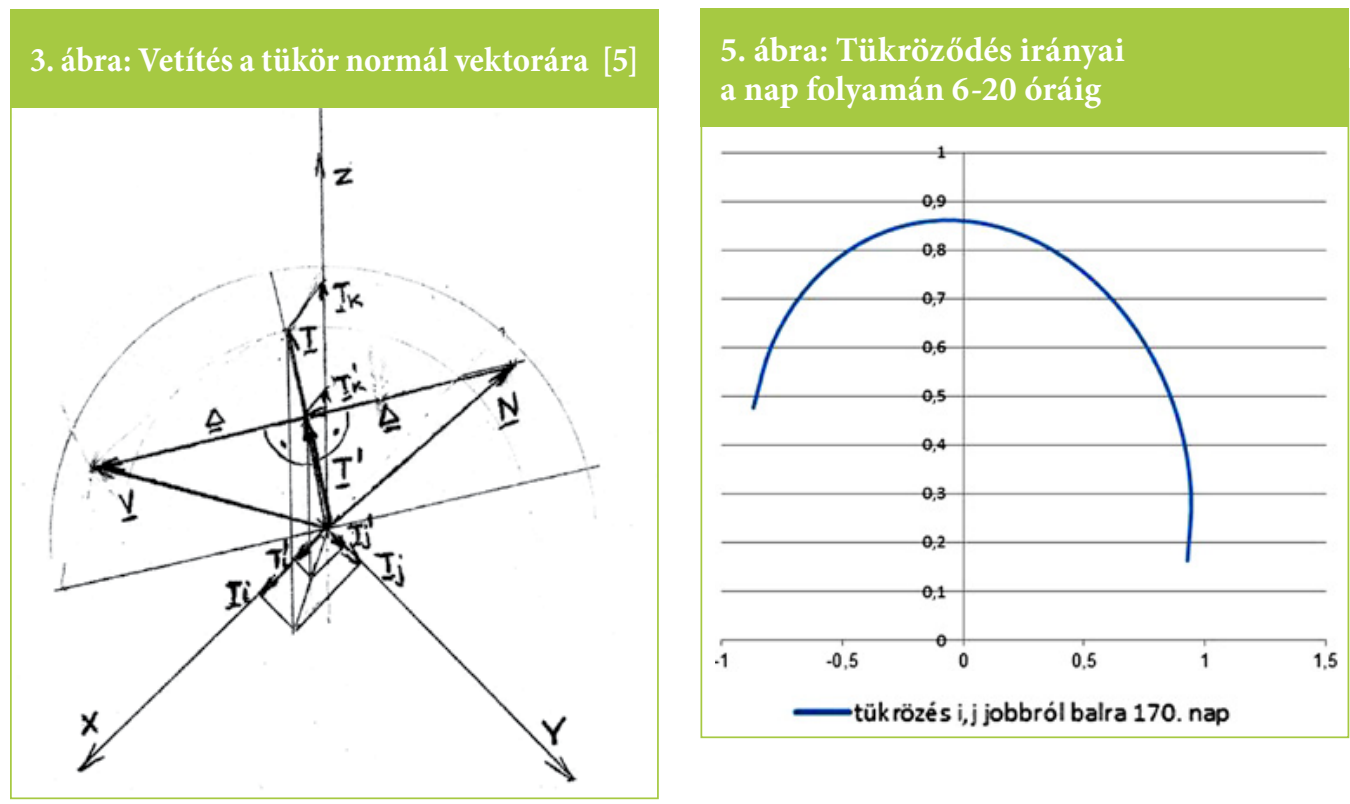

Alapadatok a számításnál:

- $\Psi$ A tükröző felület földrajzi szélessége 47 fok,

- tükör elforgatás déltől +30 fok (nyugatra),

- hossza $1 \mathrm{~m}$,

- süllyesztés -0,705 m,

- koordináta rendszer X nyugat, Y dél, Z magasság.

A 3. ábra mutatja a visszaverődés $\underline{\mathrm{V}}$ vektor kiszámításának módját.

4. ábra: Az N Nap pályáját leíró vektor balról jobbra halad az idópontokban 6-20 óráig

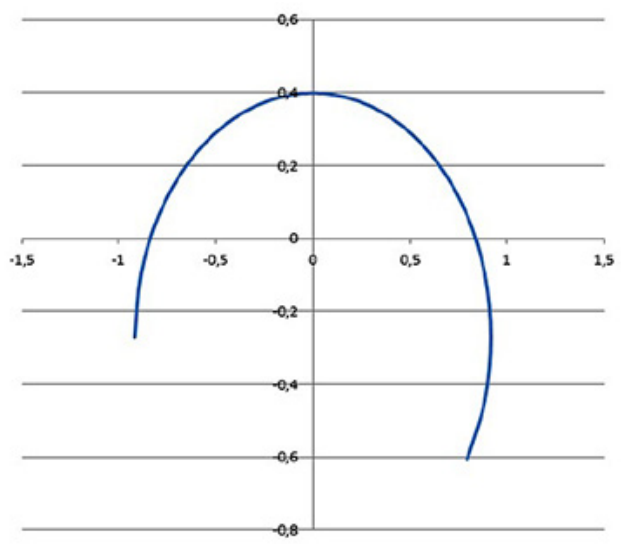

— Napvektor 170 . nap i,j komponens idöskála balról jobbra

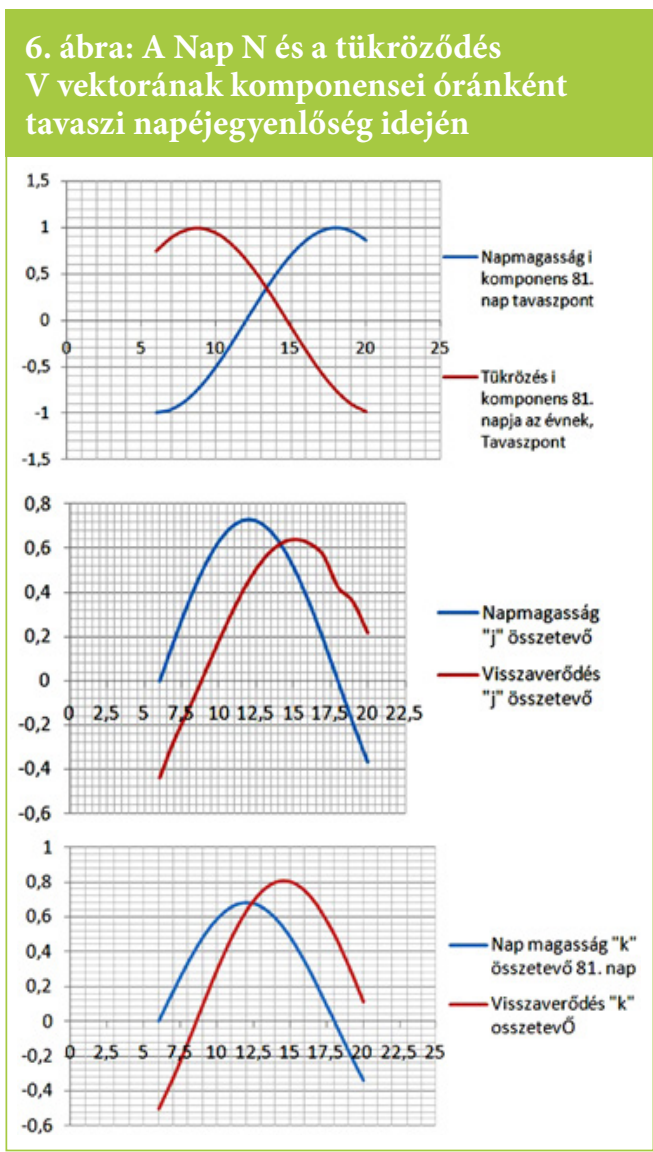




\section{Légi közlekedés}

$\underline{T^{\prime}}-\underline{N}=\underline{\Delta}$

A különbség vektor merőleges a $\underline{T}^{\prime}$ vektorra mert az az $\mathrm{N}$ vektor vetülete,

$\underline{T^{\prime}}+\underline{\Delta}=\underline{\mathrm{V}}$

Kiadja a tükörképét az $\underline{\mathrm{N}}$ vektornak, ami a $\underline{\mathrm{V}}$ visszaverődés vektora

$\underline{\mathrm{V}}, \underline{\mathrm{T}}, \underline{\mathrm{N}}, \underline{\mathrm{T}}$ egy síkban vannak.

A 81. napon a visszaverődés szempontjából nem kell azokat az időpontokat figyelembe venni, ahol a diagramokon a „k" komponensek értékei mind Nap, mind a visszaverődés esetén negatív értéket vesznek fel.

A 170. napnál nem kell azokat az időpontokat figyelembe venni a visszaverődés szempontjából ahol a diagramokon a „k” komponensek értékei mind Nap, mind a visszaverődés esetén negatív értéket vesznek fel. (Pl. Nap a horizont alatt, tükrözés horizont alá.)

Amikor nincs teljes visszaverődés, akkor $15 \%$-ra tehető a szóródás. A napelemeket és a

\section{7. ábra: A Nap N és a tuikröződés V vekto- rának komponensei óránként nyári nap- forduló idején}

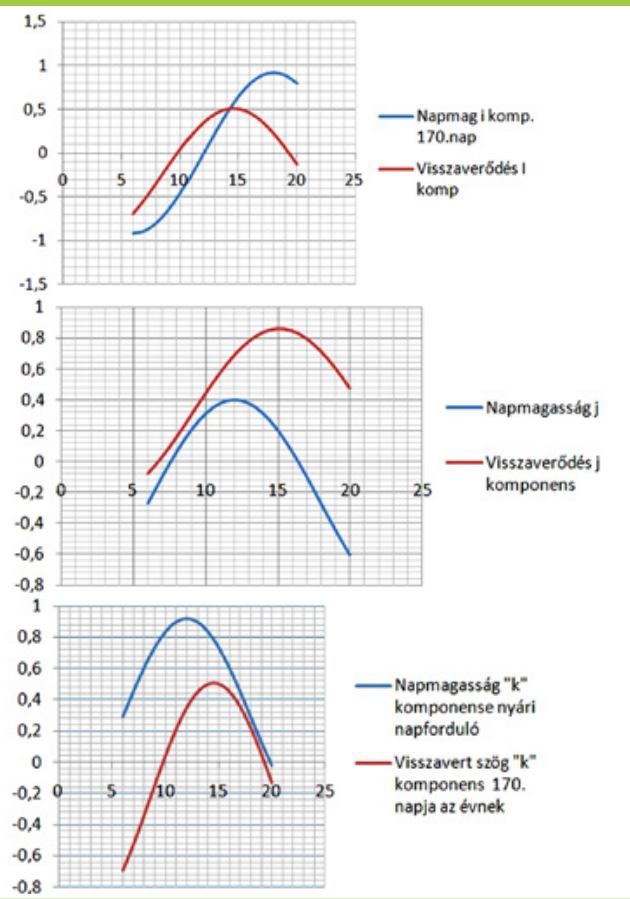

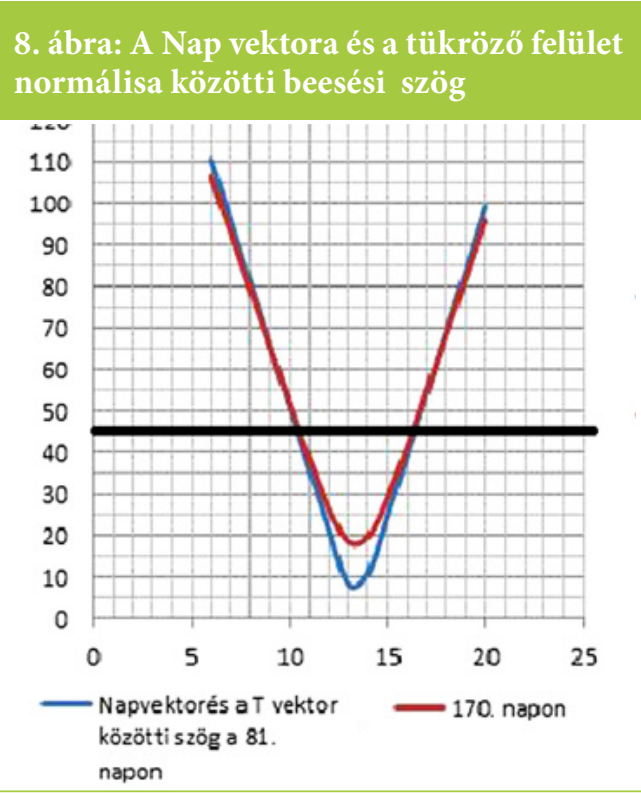

kollektorokat többnyire üveg, esetlegesen müanyag borítja. Ilyenkor átlagosan $n=1,47$ közismert értékkel számolva, $45^{\circ}$-os beesési szög felett történik meg csak a teljes visszaverödés. Víz esetén $\mathrm{n} \sim 1,3$.

A 8. ábra azokat az időpontokat mutatja, hogy a számításunk alapadatai szerinti esetben, mikor kell számítani teljes visszaverődésre Vízszintes tengely a napi időskála. A vastag fekete vonal felett történik meg teljes visszaverődés. Ezeknél a készülékeknél, sajnos nemigen számíthatunk 1,4-nél kisebb törésmutatójú fedőanyagra.

Megjegyzés: a Napvektor pályájának számítására a fent leírt számítási módszer [3] képleteit alkalmaztuk. Csak a továbbiakban térte át a gömbháromszög alkalmazásáról vektorokkal történő számításra. Ilyen tükröző felület beállításnál a 6-20 óráig történő számítás elegendőnek bizonyult.

\section{KUTATÁS A CSENDES-ÓCEÁN FELETT, EGY SZERENCSÉS KIMENETELÜ ESEMÉNY ISMER- TETÉSE}

1978. december 21-ét írtunk. Ezen a gyönyörü szép téli napon, amikor már mindenki a ka- 


\section{Légi közlekedés}

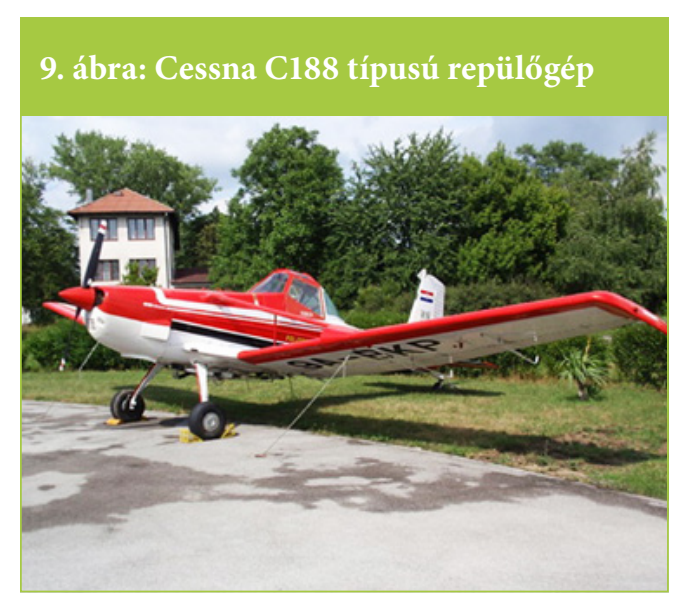

rácsonyi készülődéssel volt elfoglalva, a világ túloldalán, a déli féltekén egy kisrepülő pilótája komoly bajba került, majdnem végzetesen eltévedt. Lássuk, hogyan történt az az esemény, amely kis híján a repülőgép, és annak vezetője elvesztéséhez vezetett, és milyen szerepe volt a Napnak abban, hogy a pilóta eltévedt, majd pedig abban, hogy végül megtalálták.

Jay Prochnow, a vietnami háború veteránja, gyakorlott pilóta volt. 1978 decemberében egy társával együtt azt a feladatot kapta, hogy két Cessna 188 típusú, mezőgazdasági célokra szolgáló repülőgépet a californiai Oakland repülőteréről Ausztráliába, Perthbe vigyenek.

\section{0. ábra: A kontinensek közötti útvonal}

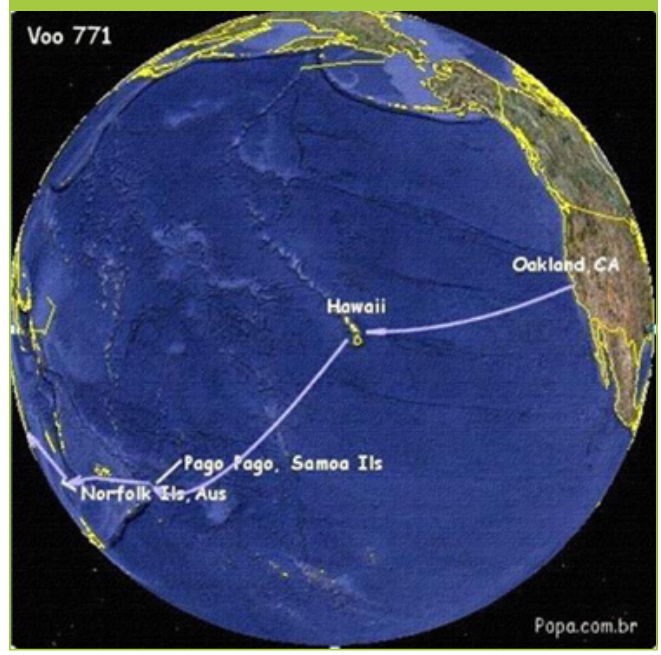

Az út már a megtervezésekor sem tünhetett veszélytelennek, azonban a repülőgépek ilyen módon történő szállítása jóval olcsóbbnak látszott, mintha mindezt hajóval tették volna meg (9. ábra).

$\mathrm{Az}$ eredeti tervek szerint Oaklandból $\mathrm{Ha}$ waiira, onnan a Pago-Pago szigetre (Amerikai - Szamoa), innen Norfolk szigetére, végül Ausztráliába kellett volna repülniük.

Az út Pago-Pagoig bonyodalmak nélkül zajlott. Innen december 20-án indultak volna tovább, a másik gép azonban nem sokkal a felszállás után, Prochnow szeme láttára az óceánba zuhant. A pilótát végül szerencsére sikerült kimenteni, azonban - nyilván a történtek hatására - Prochnow a visszafordulás mellett döntött, és csak másnap, 21-én hajnalban indult tovább, most már egyedül.

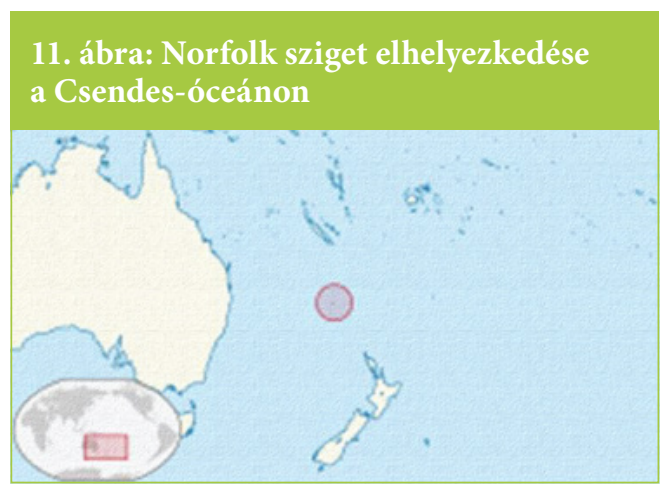

A Norfolk-sziget egyike a Csendes-óceánból felbukó számtalan sziklaszirtnek, legnagyobb hossza $5 \mathrm{NM}$ (tengeri mérföld, $1 \mathrm{NM}=$ 1852 méter), szélessége valamivel több, mint 3,5 NM, legmagasabb pontja mintegy 230 méter. Nem mondható tehát az óceán felett átívelö, nagy távolságú repülések ideális célállomásának, ahol több órán át sehol sem látható tájékozódásra alkalmas tereptárgy, és sokszor az irányadók is messze vannak. Norfolktól Ausztrália 750, Új-Kaledónia 350 és Új-Zéland legészakiabb része is 400 tengeri mérföld távolságra van.

A Pago - Pago és Norfolk közötti távolság 1450 NM, és az irányszög az Egyenlítőtől Dél felé távolodva már az út felénél, folyamato- 


\section{Légi közlekedés}

san, 4 fokkal változik, ha a pilóta ortodromán szándékozik elérni a célrepülőteret.

110 csomó ( $205 \mathrm{~km} / \mathrm{h})$ sebességgel repülve Jay Prochnow 14 - 15 óra repülési időre számíthatott, de a biztonság kedvéért 22 órára elegendő üzemanyagot tankolt Pago-Pagon.

Másnap reggel, 1978. december 21-én, helyi idő (LT) szerint 03 óra 00 perckor szállt fel újból. Ezen a napon a napfelkelte 5 óra 15 perckor volt: Prochnow úgy számította, hogy a dátumvonalat reggel nyolc órakor éri el. Ez így is történt, azaz a pilóta 1978. december 21-én, reggel nyolc órakor egy napot ugrott elöre az időben, és számára december 22-e „lett”.

A déli féltekén ezen a napon van a nyári napforduló, és a Baktérítőnél, ahol Prochnow elkezdte teljesíteni útvonalát, ekkor mintegy másfél órával tovább tartózkodik a mennybolton a Nap.

Vagyis a déli féltekén ez az a nap, amikor a legtovább van világos.

A pilóta rendelkezésére álló navigációs eszközök meglehetősen szegényesek voltak, hiszen a légiforgalmi térképén, és a mágneses iránytűn kívül csupán egy ADF rádióiránytü (Automatic Direction Finder - 12. ábra) állt a rendelkezésére.

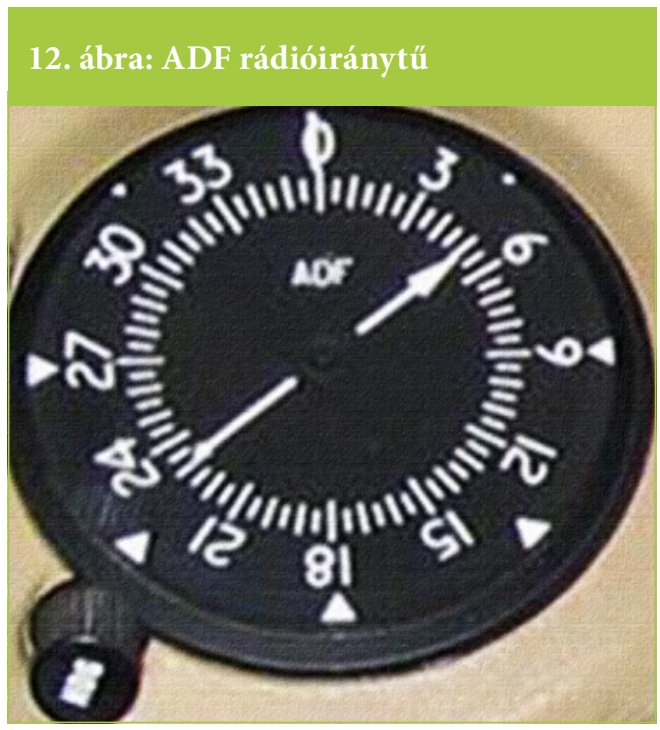

Mielőtt tovább követnénk Prochnow útját, szenteljünk néhány gondolatot e müszer müködésének.

Ez a berendezés az un. NDB (non-directional beacons, rádió irányadó) vevő egysége, amely irányadókat elszórtan telepítettek a különböző szigeteken. Az irányadók a távoli helymeghatározáshoz ugyan túlságosan pontatlanok, azonban sugárzásuk meglehetősen erős, jelük nappal akár 300 NM-ről, éjjel pedig már 700 NM-ről észlelhető volt, már történetünk idején is. Az ADF egységet rá lehet hangolni egy kiválasztott NDB-re, az így kapott irányszög, és az iránytű által jelzett mágneses észak segítségével pedig meg lehet határozni a repülőgép mágneses irányszögét és a távoli adóhoz viszonyított irányszögét. Két-három további mérés esetén a repülőgép viszonylagos helyzete is meghatározható. Nagy távolságok megtétele esetén azonban az ADF vadul ingadozik, így a pontos navigálás ezzel az eszközzel szinte lehetetlen, illetve arra csak akkor van lehetöség, amikor a repülőgép már a célállomásának NDB adója hatókörzetébe kerül. Ekkor ugyanis egészen egyszerüen követni kell az ADF által mutatott irányt, amely így az adóhoz vezet.

13. ábra: Az erős tükröződéssel párosulva a napfény elvakítja a pilótákat, és ezért nem látják a légtér jelentős részét

A tervezett érkezési idő 16:00 (LT) volt. 16.30kor az ADF még mindig előre mutatott. Ekkora távolságnál ugyan harminc perc eltérés még akár normális is lehet, ám a pilóta mégis gyanút fogott, és müszerét ráhangolt más NDB adókra is, de az így meghatározott pozíciók rajta sem voltak a térképén. Ismét ráhangolta készülékét Norfolk NDB-re. A müszer most teljesen más irányt mutatott mint előzőleg. 


\section{Légi közlekedés}

Ekkor felismerte, hogy hosszabb ideje rossz irányba repült! Megpróbálta szabad szemmel megkeresni a kis szigetet, azonban a Baktérítő mentén, nyugatnak repült, naplementekor.

Ilyenkor mit lehet látni egy nyílt óceán felszínén? A tájékozódás szabad szemmel gyakorlatilag lehetetlen, amikor, párosulva az erős tükröződéssel, a napfény elvakítja a pilótákat, és ezért nem látják légtér jelentős részét. (13. ábra)

Az óceán felszínén, illetve a felette lévő légtérben jellemzően van forgalom. Most viszont egyáltalán nem volt. Sem vízi sem légi forgalom.

Prochnow felmérte a helyzetét. Tüzelöanyaga volt még bőven, ami mintegy hét órányi repülésre volt elég.

Reménytelenül eltévedt. Kapcsolatba lépett Aucklanddel, ismertette a kialakult szituációt, és vészhelyzetet jelentett.

Ez alatt 17:15 kor a Fidzsi-szigetekről felszállt az Air New Zealand DC 10-es típusú, ZK-NZS lajstromjelü repülőgépe, a TE 103-as számú járat teljesítésére Auckland felé, amely az utazómagasság elérése után értesült a problémáról. A személyzetük megérdemli, hogy $\mathrm{mi}$ is ismertté tegyük nevüket.

Gordon Vette kapitány

Arthur Dovey első tiszt

Gordon Brook fedélzeti mérnök, valamint

Malcom Forsyth, a légitársaság egyik első tisztje, aki utasként tartózkodott a fedélzeten.

Szerencse volt a szerencsétlenségben, hogy Vette kapitány nem csak tapasztalt pilóta volt, de lelkes navigátor is volt. A légitársaság ebben az időben még üzemeltette a DC 8-as típust, amelyen rendszeresen navigátorként repült.

A DC 10-es típus ugyan már ekkor is rendelkezett radarral, az azonban csak a nagyobb viharfelhők, időjárási események azonosítására volt alkalmas, egy ilyen kis repülőgép észlelésére nem.

Az utasszállító személyzete tájékoztatta az utasokat a kialakult helyzetről, valamint arról,

\section{4. ábra: Egy Air New Zealand DC-10}

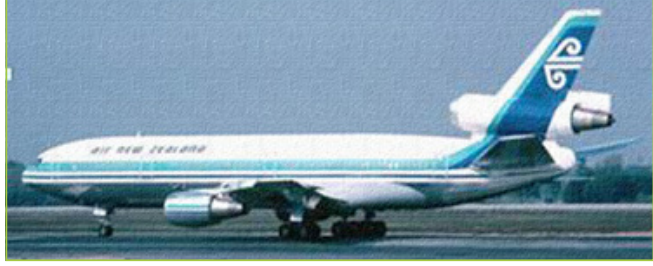

hogy az eredetileg rövidre tervezett út lényegesen tovább fog tartani, mint gondolták, és bevonták az utasokat is a kutatásba. (Több szem többet lát.)

Az új- zélandi légierő egyik ORION-ja szintén készenlétben állt, azonban annak bázisa több órára volt a feltételezett feltalálási helytől. A legközelebb az Air New Zealand TE 103-as járatát teljesítő DC 10 -es repülögép volt, az előbb említett személyzettel.

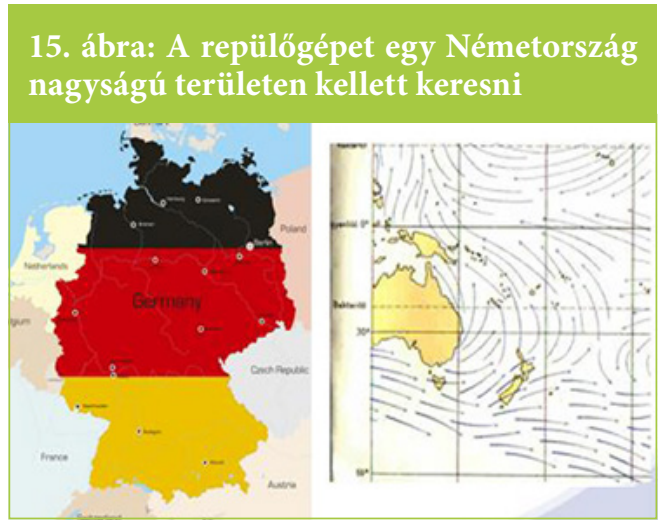

Az eltévedt repülőgépet Ausztráliától Keletre, nagyjából egy mai Németország nagyságú területen kellett megkeresni. Arra szinte azonnal rájöttek, hogy hibás lehet az $\mathrm{ADF}$, de nem tudták, mi a baj, és azt sem, hogy a Cessna emiatt 200 NM-re délkeletre került Norfolktól.

Az eltévedt repülőgép helyzetének hozzávetőleges meghatározására szükség lett volna egy pontos navigációs térképre, azonban ilyen „hivatalosan" nem volt a fedélzeten. Szerencséjük volt, Vette táskájában véletlenül volt egy. 


\section{Légi közlekedés}

A nap irányába fordították mindkét gépet, és leolvasták az iránytüről az irányszöget, az ú. n. azimut szöget. Az eredmény:

Cessna: $274^{\circ}$

DC 10: $270^{\circ} \mathrm{f}$

Vagyis: a Cessna délebbre volt a DC10-nél!

A cikk elején található (3) egyenlet az azimut irányszög számításához, amelyet mindkét repülőgépre alkalmazva

$\sin a=\frac{\cos \delta}{\cos m} \sin \omega$

szerint a Cessna azimutja, más szóval irányszöge, akkor lehet azonos $\omega$ óraszögnél nagyobb, mint a DC10-es irányszöge, ha az általa mért cosm értéke kisebb. Ám a keresett Cessna mért irányszöge $4^{\circ}$-kal több volt. Ha a Cessna óraszöge Kelet felé térne el, szintén csökkenne az azimut. Így feltételezhető volt, hogy a kereső DC10-es repülőgéptől nem az egyenlítő irányában keresendő az eltévedt repülőgép.

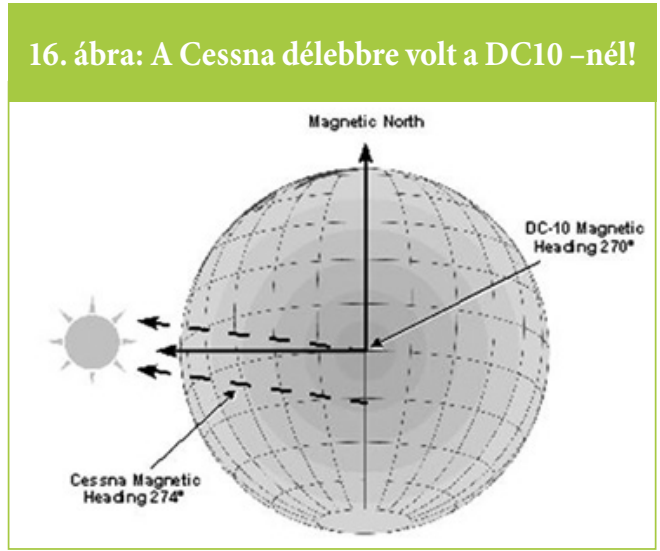

Azért azt nyilván nem feltételezték, hogy a két repülőgép között óriása a távolság, hiszen a rádiók hatókörén belül voltak. Ezért Vette ötlete alapján, azonos magasságon lemérték, hogy hány ujjuk fér a nap és a horizont közé, az arcuktól $30 \mathrm{~cm}$-re.

Eredmény: Vette 2 ujj, Prochnow: 4 ujj.

\section{A Cessna lényegesen nyugatabbra volt a DC10 -esnél!}

A két eredményt összevetve:

$\mathrm{Az}$ elég nagyra adódó napmagasság miatt a
17. ábra: A nyugati eltérés óraszögének becslése a Napmagasság összehasonlításával

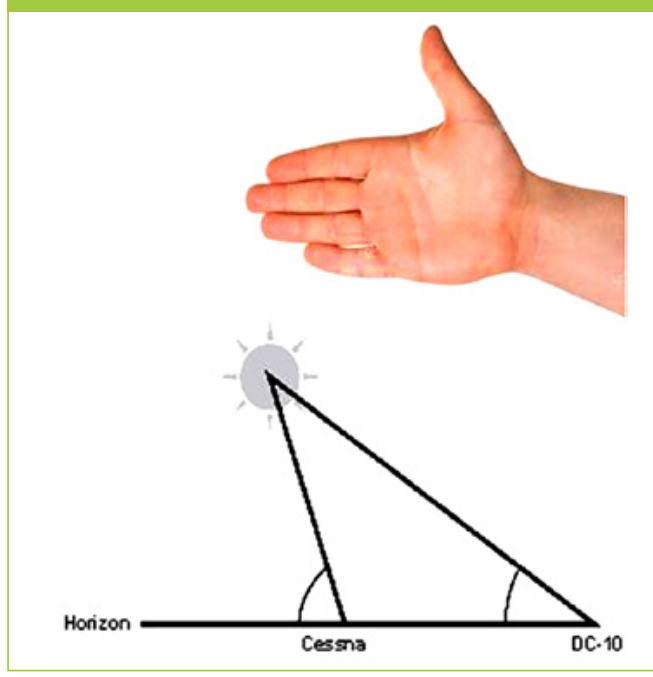

fenti (2) egyenlet alapján is elég nagy kvalitatív különbség adódott a két repülőgép óraszögét illetően, ha nem is pontosan számolva

$$
\sin m=\sin \delta \sin \Psi+\cos \delta \cos \Psi \cos \omega
$$

A DC 10-es pilótái természetesen nem végezetek ilyen komoly számításokat, de a két mérés eredményeit összevetve számukra egyértelműen megállapítható volt, hogy a Cessnát a DC10-es pozíciójához képest délnyugatra kellett keresni.

Ez már olyan eredmény volt, amely alapján a kutatás-mentési feladatot el lehetett kezdeni.

A DC 10-es pilótái azonban közben továbbra sem tétlenkedtek.

Mivel Prochnow is, és a DC 10-es személyzetének néhány tagja is korábban harci repülő volt a légierőknél, sok tapasztalattal rendelkeztek sérült, vagy eltévedt bajtársaik hazavezetésében, illetve a tanker gépre való rávezetésben. Emellett Vette amatőr tengeri vitorlázó volt, és éppen nála volt az Óceániára vonatkozó tengerészeti térkép, így jó eséllyel tudtak egymásnak tanácsokat adni. Megpróbálták a becsült koordinátájú térséget megközelíteni, de az üzemanyag fogyasztás mérséklése miatt már nem süllyedhettek kis magasságra. A DC 10-es 


\section{Légi közlekedés}

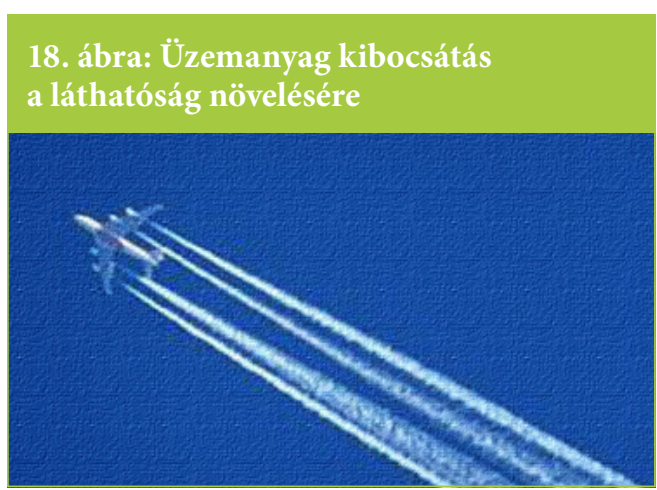

személyzete a láthatóságukat is növelése végett üzemanyag kibocsátásával próbált égi jelet húzni, mivel a trópusi nyárban a hőmérséklet miatt nem húztak kondenzcsíkot.

A várt találkozás nem jött létre, kondenzcsík nem volt, az üzemanyag kibocsátása pedig nem vezetett eredményre.

\section{9. ábra: A DC-10-es útja}

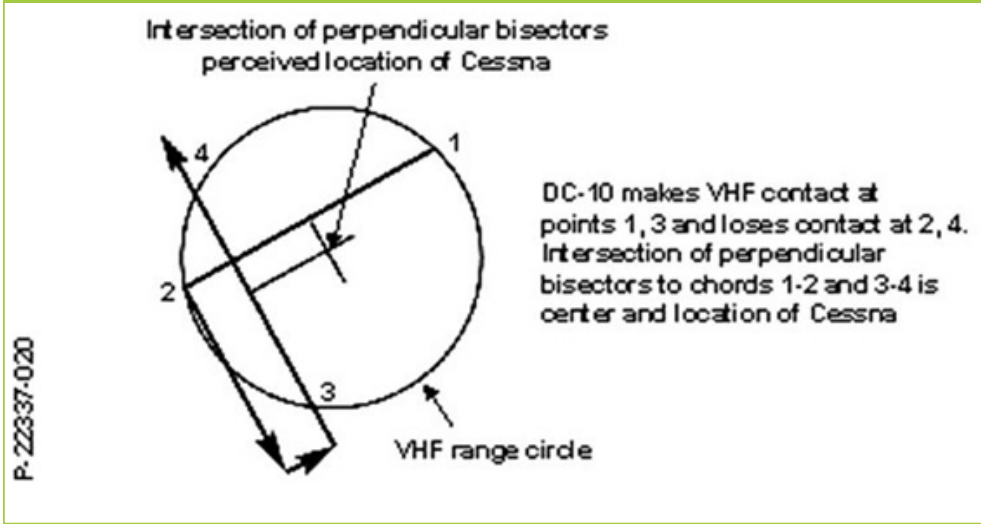

20. ábra: A háromszög oldalfelezó merölegesei a köré írható kör középpontjában metszik egymást

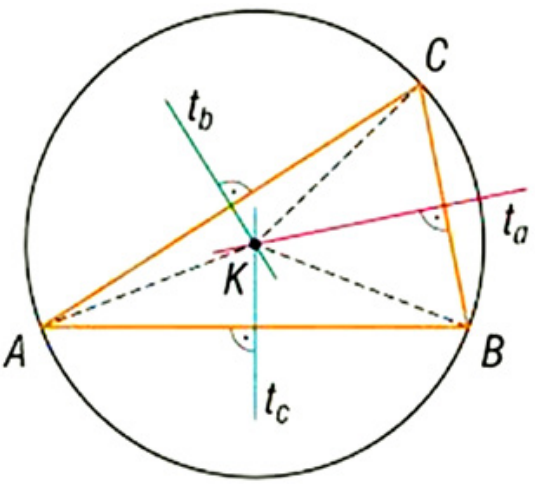

Ezután dél-keletnek, majd északnak fordulva megint létrejött a kapcsolat, azt is bejelölték a térképen, majd a korábbi irányra merőlegesen repülve megjelölték a kapcsolat megszüntének helyét. Az így kapott pontokat összekötve hozzávetölegesen meghatározható volt a Cessna pozíciója.

Geometriai alaptétel, hogy a háromszög oldalfelezőinek metszéspontja megadja a köré írható kör középpontját, így megtalálhatták az adott rádióadó helyét, vagyis a keresett repülőgépet.
Ekkor un. „hallhatósági próbát” végeztek, illetve segítségül hívták a matematikát.

A DC 10-es személyzete figyelni kezdte, hogy mikor jön létre a kapcsolat a 121,5 MHz-es vészhelyzeti frekvencián. Amikor ez megtörtént, akkor bejelölték pozíciójukat a térképen. Prochnow-t arra kérték, hogy próbáljon meg körözni, folyamatosan beszéltették, miközben elfordultak, majd amikor a kapcsolat megszünt, ismét megjelölték helyzetüket a térképen.

\section{FÉNY A TENGEREN}

A várt találkozás azonban ismét elmaradt, azonban új remény támadt a megmenekülésre, Prochnow ugyanis fényt vett észre a tengeren. A DC 10-es pilótái kapcsolatba léptek a hajózási szervekkel, amelyek tájékoztatták őket, hogy az kizárólag a „PENROD” nevü úszó olajfúró torony lehet. A tengerészeti koordinációs központ tájékoztatása szerint a PENROD helyzete: Déli szélesség $31^{\circ}$ 


\section{Légi közlekedés}

21. ábra: Ilyen lehetett a Csendes-óceán 1978. december 22-én (Illusztráció)

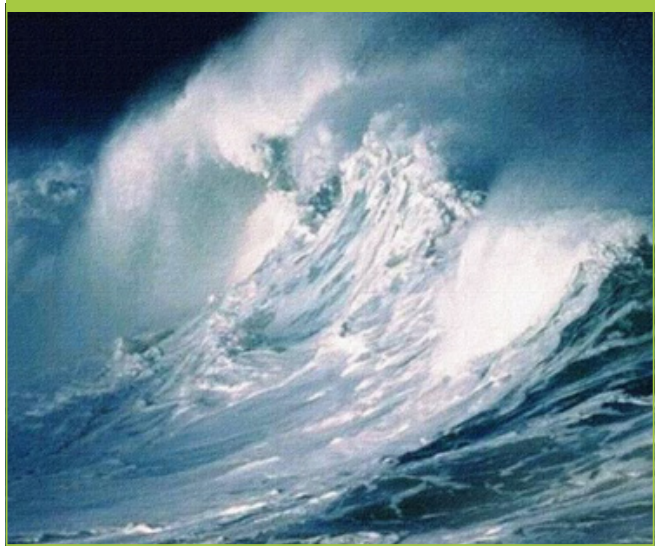

Keleti hosszúság $179^{\circ} 21^{\prime}$

600 NM - re Norfolktól keletre.

Prochnownak nem volt semmi esélye.

A PENROD észrevette a repülőgépet, felkészült a mentésére. Prochnow felkészült a vízre szállásra, leereszkedett megnézni a vízfelszínt, azonban amit látott, az ismét elszomorította, a hullámok 5-6 méter magasak voltak.

A DC10-es nagy sebességgel közeledett a megadott koordináták felé, azonban ismét azt kellett feltételezniük, hogy valami nincs rendben. Folyamatosan romlott ugyanis a rádióadás minősége ahelyett, hogy egyre tisztábban hallották volna egymást.

Mivel ekkor már kapcsolatban voltak a PENROD-al, megkérték, hogy erősítse meg a pozícióját.

Az olajfúró torony személyzete azonban más koordinátákat adott, szerintük a pozíciójuk helyesen:

Déli szélesség $31^{\circ}$

Keleti hosszúság $170^{\circ} 21^{\prime}$ volt.

A Cessna nem 600 NM-re volt Norfolktól, hanem csak 150-re. Kiderült, hogy a központban valaki egy nullát kilencesnek olvasott.

A kisgép pontosan ott volt, ahová a DC 10-es személyzete mérte. (A történtek későbbi re- konstruálása során kiderült az is, hogy a várt találkozás azért nem jött létre, mert a DC 10 -es éppen a Cessna felett volt, amikor tüzelöanyagot eresztett ki, de a naplemente által keltett fényviszonyok a két gép egymáshoz képesti helyzetét is figyelembe véve, lehetetlenné tették az így keletkező csík észlelését.)

Forsyth számításai szerint a Cessna ekkor mintegy egy órai repülésre volt Norfolktól, azonban a rendelkezésre álló tüzelőanyag mostmár veszélyesen fogyott. Az eredeti számítások szerint már csak mintegy fél órára elegendő üzemanyag állt a rendelkezésére, Prochnow a készleteket felmérve úgy számolta, hogy kb. egy óra tizenöt percre elegendő van még. A háborgó tengert látva azonnal döntött: megpróbál eljutni Norfolk szigetéig.

A DC 10-es óvatosan elé ment, és mutatta az utat. Közben az ORION is odaért, és végül, helyi idő szerint éjfélkor a Cessna landolt a norfolki betonon úgy, hogy az elvileg huszonkét órára elegendő tüzelőanyaggal huszonhárom óra öt percet repült.

A TE 103-as számú járat a menetrendben foglaltakhoz képest három óra negyvenöt perces késéssel, biztonságosan megérkezett Aucklandbe. Ezúttal senki nem tett panaszt a késésért.

A DC 10-es személyzetének valamennyi tagja kitüntetésben részesült.

Gordon Brooks azonban sajnos nem sokáig örülhetett ennek, mivel 1979. november 28-án életét vesztett egy, az Antarktiszon bekövetkezett balesetben.

Gordon Vette kapitány később könyvet írt a balesetről, „Ütközés az Erebusznál” címmel. Az eseményt követő vizsgálat kimutatta, hogy azt egy igen banális hiba, az ADF tüjének kilazulása okozta. A müszer tehát tulajdonképpen jól müködött, „csak” az irányt jelző tü mutogatott össze-vissza. 


\section{Légi közlekedés}

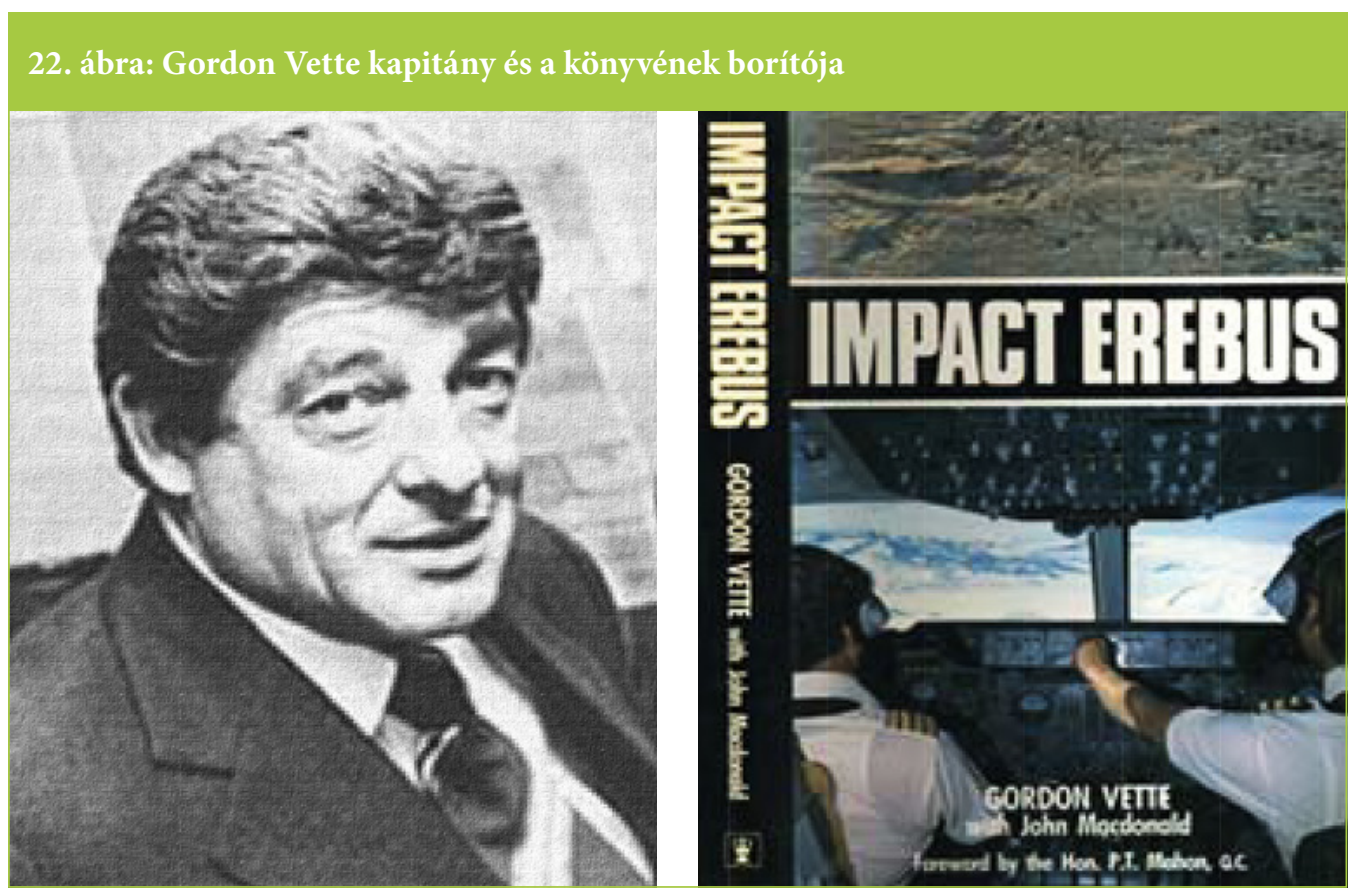

\section{FELHASZNÁLT IRODALOM}

[1] https://hu.wikipedia.org/wiki/Nap (Hatások az emberi szervezetre)

[2] Google Earth: A Föld napéjegyenlőség időpontjában. A Nap 6 órakor Keleten kel

[3] napenergia.freeweb.hu/htmlszak/sz2hova Amit a napenergia hasznosításáról feltétlen tudni kell. Kis-Pap László/ 2002-2003 Napkollektorok. Elhelyezések és mozgatások

[4] 1. ábra Jantar Mantar, foto dr. Sobor Ákos 2015.11.10 és a Téli Kis Napóra, foto Orbánné Szöllösi Györgyi 2015.11.10, Jaipur

[5] Reiman István: Matematika, Müszaki Könyvkiadó, Budapest,1992.

[6] Dr. Budó Ágoston: Mechanika, IV. kiadás Tankönyvkiadó, Budapest 1965

[7] Rühl Lajos: Csillagászati navigáció, Tankönyvkiadó, Budapest 1970: III. és VIII. fejezet

[8] Csendes-óceáni keresés (In.: Stanley Stewart: Vészhelyzet a repülőgép fedélzetén Müszaki Könyvkiadó Budapest, 1994.)

[9] Cessna C180 típusú repülőgép https:// en.wikipedia.org/wiki/Cessna_188_ Pacific_rescue
[10] A kontinensek közötti útvonal https:// acervo.popa.com.br/_2009/CRONICAS/ voo771.htm

[11] Norfolk sziget elhelyezkedése a Csendesóceánon; forrás: internet

[12] ADF rádióiránytü http://www.iainhosking. com/flying/aviation_glossary.php

[13] Az erős tükröződéssel párosulva a napfény elvakítja a légtér jelentős részét; forrás: internet

[14] Egy Air New Zealand DC-10 https://www. airliners.net/photo/Air-New-Zealand/ McDonnell-Douglas-DC-10-30/393908

[15] A repülögépet egy Németországnyi területen kellett keresni http://drot.eu/article/ csak-szervezes-kerdese-menekulteknemetorszagban

[16] A Cessna délebbre volt a DC10 -nél! https:// acervo.popa.com.br/_2009/CRONICAS/ voo771.htm

[17] A nyugati eltérés óraszögének becslése a Napmagasság összehasonlításával https:// acervo.popa.com.br/_2009/CRONICAS/ voo771.htm

[18] Üzemanyag kibocsátás a láthatóság növelésére www.femcafe.hu/cikkek/lifestyle/ 
valoban-mergezo-a-kondenzcsik-lerantjuka-leplet

[19] A DC-10-es útja https://acervo.popa.com. br/_2009/CRONICAS/voo771.htm

[20] Háromszög oldalfelező merőlegesei a kör középpontjában metszik egymást http:// egyetemi.hu/fajlok/archimedes/2013/7-8_ tetel.pdf

[21] 1978, december 22 a Csendes-óceán http:// kepek.4ever.eu/termeszet/tengerek-estengerpartok/viharos-tenger-148822

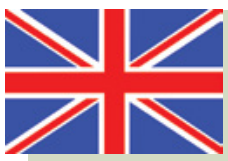

\section{Vector calculation of the reflection of the sun and the presentation of a fortunate event}

Aircraft orientation can be made difficult by beams of light, in some cases reflected, blinding the aircraft crew. Intentional laser interference is a well known issue, but such events can also occur in the case of natural light reflection. Not only the sun near the variable horizon, but the sunlight reflected from reflecting surfaces - e.g. glazed surfaces, water surfaces etc. - can also be disturbing. In addition to the calculations and the description of the scientific bases, the article also describes an almost tragic aviation incident over the ocean.

\section{Légi közlekedés}

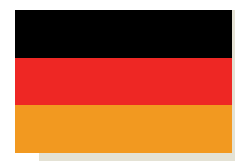

\section{Vektordefinition der Reflexion der Sonne und Darstellung eines glücklichen Falls}

Die Orientierung der Flugzeugs kann durch Lichtstrahlen erschwert werden, die in manchen Fällen reflektiert werden und die Flugzeugbesatzung blenden. Es sind absichtliche laserinduzierte Störungen bekannt, aber auch durch natürliche Reflexionen können solche Ereignisse verursacht werden. Nicht nur die Sonne in der Nähe des variablen Horizonts, sondern auch das Sonnenlicht, das von reflektierenden Oberflächen reflektiert wird - z.B. verglasten Oberflächen, Wasseroberflächen usw. -, können auch störend sein. Neben den Berechnungen und der Darstellung der wissenschaftlichen Grundlagen beschreibt der Artikel auch ein fast tragisches Flugereignis über dem Ozean.

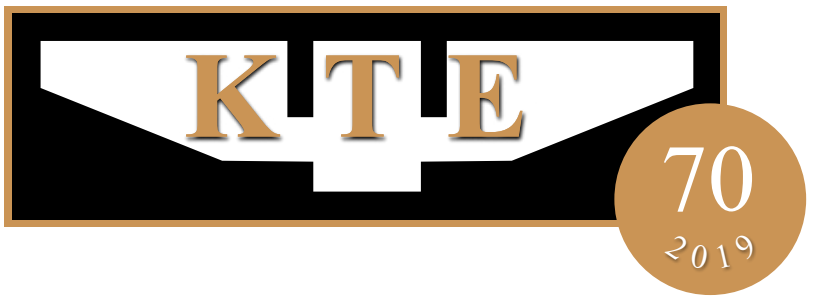

